\title{
International Law
}

\section{The Substantive/Procedural Distinction: Law's Solution to the Problem of Jus Cogens in a World of Sovereign States}

\author{
By Mark P. Hanna*
}

\begin{abstract}
This Article uses social systems theory to examine the increased reliance on a distinction between substantive and procedural international law to resolve cases involving a conflict between jus cogens and state immunity. This presents the problem of an evolutionary relationship between international law and the complex differentiation of world society. International law is shown to be structurally related to the segmentary differentiation of states that underwrites modern society's functional differentiation. At the same time, it is shown to be structurally related to the increasing formulation of global norms that result from advanced functional differentiation. The Article then turns to examining the substantive/procedural law distinction as a solution to this dual functional reference problem. The distinction is shown to not only maintain the autopoiesis of law under these difficult conditions, but to also secure law's continued functional relevance in globalized society. This functionalist perspective is used to expose differences in the self-description and operation of international law, to point out how law has been blind to its own coding, and to highlight opportunities for programming law to respond in a more constructive manner to the challenges of globalization.
\end{abstract}

*School of Law, Queen's University Belfast. I am grateful to Lyana Francot for her comments on an earlier draft. 


\section{A. Introduction}

Expectations of jus cogens found their first real positive formulation in law during the 1950s when lawyers like Alfred Verdross and Hersch Lauterpacht asserted them through their work for the International Law Commission on the codification of treaty law. ${ }^{1}$ The resulting provision in the 1969 Vienna Convention of the Law of Treaties - that any treaty would be void if it violated a "norm accepted and recognized by the international community of States as a whole as a norm from which no derogation is permitted" 2 -may have been merely symbolic in that states were unlikely to make a treaty to violate such a peremptory norm in practice. Yet, the provision reflected greater societal trends and ultimately provided a foothold for further expectations of global public order and the global normative hierarchy of jus cogens. In recent years, increasing calls for a more general application of jus cogens in international law and more extensive claims to peremptory norms have brought the doctrine into direct conflict with a more traditional normative structure of the international system - the jurisdictional immunities of the state. The tension here between the implicit normative hierarchy of jus cogens and the sovereign equality of states at the basis of jurisdictional immunity has presented courts with a decidedly hard case of contemporary international law. In a world society that communicates at the global level and obviously shares global problems, expectations of global public order can hardly be denied. And yet, with the extent to which institutionalized steering mechanisms remain dependent on the political authority of the nation-state, ${ }^{3}$ expectations of state sovereignty and independence must also be maintained.

The solution provided by courts is subtle and yet profoundly significant for the development of international law. Eschewing any reliance on "principles" - which is arguably of limited application to hard cases of international law ${ }^{4}$-international, regional, and national courts

\footnotetext{
1 Verdross published an article in 1937 introducing the option of a positive legal limitation on the freedom of contract which nation-states enjoy in making treaties, and could realize this concept further when he was elected a member of the International Law Commission in 1957. Alfred von Verdross, Forbidden Treaties in International Law, 31 AM. J. INT'L L. 4, 571-77 (1937). Once elected as Special Rapporteur in 1953, Lauterpacht submitted a draft provision suggesting that a treaty is void if its performance involves any violation of the overriding principles of international law, Special Rapporteur Hersch Latuerpacht, The Ordre Public International, Law of Treaties: Report by Special Rapporteur, 2 Yearbook of the International Law Commission, U.N. Doc. A/CN.4/63.

2 See Vienna Convention on the Law of Treaties arts. 53, 64, and 66(a), May 23, 1969.

${ }^{3}$ This is not to overlook the fragmented and polycentric nature of global governance, whereby a multiplicity of nonstate actors also contribute to achieving collective goals. See, e.g., James Rosenau, Change, Complexity and Governance in a Globalizing Space, in DEBATING GoVERNANCE 172 (Jon Pierre ed., 2000) (on such a broad definition of global governance). Nevertheless, the engagement of nation-states clearly remains essential to achieving lasting solutions to many global problems. Moreover, one must take account of the continued semantic value of the nation-state as a subject in the modern international legal system.

${ }^{4}$ As per Lord Hoffmann of the British Supreme Court, the "same approach cannot be adopted in international law, which is based upon the common consent of nations," in Jones v. The United Kingdom of Saudi Arabia, House of Lords, [2006] UKHL 26, para. 63., but cf. HERSCH LAUTERPACHT, INTERNATIONAL LAW, Vol. 1, 69 (1970). Lauterpacht's ever
} 
have consistently opted for something more formal: Use of judicially constructed distinctions. Traditionally, this involved distinctions between the individual and the state or between criminal and civil law. But recently, in response to increasing demands of an international rule of law and claims to further state immunity exceptions, courts have been forced to develop a new distinction between jus cogens as "substantive" and state immunity as "procedural." 5

The practice has divided international lawyers and legal scholars. On the one hand, some defend the approach because jus cogens and state immunity "have different contents and therefore do not impose incompatible obligations, ${ }^{16}$ or even because the distinction ensures that proceedings move "in an orderly fashion, protecting the interests of all victims by ensuring equality and non-discrimination." ${ }^{7}$ On the other hand, some feel that the judicial use of the distinction is "unsatisfying," 8 "utterly theoretical," 9 an example of "excessive formalism,"10 or "illusory and lacking any real meaning." 11

This Article aims to move beyond these positions and instead gain a second-order perspective on law's operation with respect to jus cogens and state immunity. To gain this perspective, it will rely on the systems theory of the German sociologist, Niklas Luhmann. Luhmann originally trained and practiced as an administrative lawyer and later went on to write at least nine books on law. He never systematically addressed the subject of international law, but his theory of law and society was sophisticated enough by the early 1970s to predict the fragmentation that registered concretely for international lawyers at

\footnotetext{
relevant, but unrealized, hope for the role of general principles in the development of international law beyond pure consensualism towards the will of states.

${ }^{5}$ This is most notably expressed in the International Court of Justice's recent case, Jurisdictional Immunities of the State (Ger. v. Italy, Greece intervening), I.C.J. Rep. 2012 (hereinafter Jurisdictional Immunities).

${ }^{6}$ See Stefan Talmon, Jus Cogens after Germany v. Italy: Substantive and procedural Rules Distinguished, 25 LEIDEN J. OF INT'L L. 986 (2012).

7 See Christian Tomuschat, The Case of Germany v. Italy before the ICJ, in IMMUNITIES IN THE AGE OF GLOBAL Constitutionalism 88 (Anne Peters et al. eds., 2014).

${ }^{8}$ See Pietro Di Ciaccio, A Torturer's Manifesto? Impunity through Immunity in Jones v. The Kingdom of Saudi Arabia, 30 SYDNEY L. REV. 557 (2008).

${ }^{9}$ See Alexander Orakhelashvili, Peremptory Norms as an Aspect of Constitutionalisation in the International Legal System, in The Dynamics of Constitutionalism in the Age of Globalisation 165 (Morley Frishman \& Sam Muller eds., 2010).

${ }^{10}$ See Lorna McGregor, Torture and State Immunity: Deflecting Impunity, Distorting Sovereignty, 18 EUR. J. INT'L L. 911 (2007).

11 See Jennifer Besner \& Amir Attaran, Civil Liability in Canada's Courts for Torture Committed Abroad: The Unsatisfactory Interpretation of the State Immunity Act 1985, 16 TORT L. REV. 164 (2008).
} 
the turn of the century. ${ }^{12}$ The singular way in which this approach offers a balanced perspective on both the internal logics of the legal system and its structural relations with society encourage its application to the present study of the international legal system. ${ }^{13}$ Over the past sixty years, international law has emerged as an expansive and complex legal system that can no longer be functionally limited to facilitating relations between sovereign nation-states, but as one that also must strive to answer the normative expectations of an increasingly globalized society. ${ }^{14}$ Measuring international law's development under these conditions cannot be adequately achieved from the purely inside perspective which is adopted by most international lawyers engaged in the onerous task of dissolving the paradox and sustaining the system. Rather, it calls for a liminal position, matching observations on internal logics with observations on the limits of the international legal system and its structural relations with society.

Luhmann's approach offers such a liminal perspective, but international lawyers generally overlook the utility of this approach, rejecting it, for example, because it "does not deliver any instrument for the construction of particular norms, i.e., the core of legal work." ${ }^{15}$ Such a basis is not well-founded. In fact, Luhmann's sociological theory of law offers a much more empirical account of the core of legal work than any of the mainstream positivist international legal theories that restrict themselves to "law built upon law."16 Moreover, if the bias is informed by the common indictment of Luhmann as a defender of "technocracy,"17 it should also be pointed out that such a charge was never particularly wellfounded either. Rather than celebrating the second-order communications which accrue around problem-solution structures in society, the methodological focus on the autopoietic-that is, the self-referential and self-reproducing-nature of these communications can provide insight into the operation of social systems, measure their

\footnotetext{
${ }^{12}$ See Report of the Study Group of the International Law Commission on the Fragmentation of International Law, U.N. Doc. A/CN.4/L.628, April 13, 2006. Nevertheless, the token mention there of "functional differentiation," and the hasty conclusion there that fragmentation was business as usual for a discipline which had always dealt with the institutional and political diversity of international society suggested a limited engagement with the sociological theory which had generated the original insight. Id., paras. 7, 17.

${ }^{13}$ See RichaRd Nobles \& DAVID SCHIFF, A SOCIOLOGY OF JURISPRUDENCE 47 (2006).

${ }^{14}$ This development and its problems were eloquently expressed by the president of the International Court of Justice in his declaration in the Nuclear Weapons Opinion. See Declaration of President Bedjaoui, Legality of the Threat or Use of Nuclear Weapons, Advisory Opinion, 1996 I.C.J. Rep. 270-71.

${ }^{15}$ See Stefan Oeter, International Law and General Systems Theory, 44 GERMAN YEARBOoK INT'L L. 93 (2001).

${ }^{16}$ See Lon L. Fuller, Positivism and Fidelity to Law-A Reply to Professor Hart, 71 HARV. L. REV. 631 (1958) (borrowing Fuller's phrase).

17 See Jürgen Habermas, Theorie der Gesellschaft oder Sozialtechnologie? Eine Auseinandersetzung mit Niklas Luhmann, in THEORIE DER GESSELLSCHAFT OdER SOZIALTECHNOLOGIE 157 (Jürgen Habermas \& Niklas Luhmann eds., 1975).
} 
contribution to society, and develop critical awareness about how such self-referential communication can deviate from the interests of general society.

This Article will use Luhmann's functional differentiation theory-and specifically the theory of how social functional systems differentiate and reproduce themselves through the use of internally constructed binary codes-as an optic through which to examine the use of the substantive/procedural law distinction in cases involving a conflict between jus cogens and state immunity. The Article will present the development of this judicial device as not only securing law's autopoiesis in the face of the paradox of jus cogens in a world of sovereign states, but as also maintaining international law's functional relevance in a globalized society with its conflicting structures of state sovereignty and global public order. Examining the development through this theoretical lens will reveal critical insights and generate questions about the development of international law in this area, while also highlighting the danger of overreliance on this distinction for international law's function in globalized society.

\section{B. The Problem of Functional Differentiation}

Social systems theory has become notorious for its concept of the autonomy that social systems achieve through self-reference. In reflection, existing attempts to apply social systems theory to international law have set about the task by constructing the systemic nature of the international legal system and its hyper-differentiation from the societal environment. ${ }^{18}$ Contrary to appearances, though, social systems theory is not simply about the autonomy and closure of the social system. Instead, it perceives systemic closure as depending upon openness to the societal environment. From this perspective, the only closure that is properly achieved is the closure of self-referential communications which accrue around basic social functions, ${ }^{19}$ such as, for example, ensuring material needs are met over time or ensuring young people are schooled in constructive social communication.

This basic premise must be the starting point for any systems theoretical approach to international law. In order to gain insights into the development of the distinction between jus cogens and state immunity, it is necessary to adopt a problem-solution perspective and thereby construct the problem courts must address in the jus cogens and state immunity conflict. $^{20}$ Why is this conflict such a problem for the larger social system? Why must society's legal system maintain a simultaneous functional reference to both sides of the distinction, to both jus cogens and state immunity? Approaching the problem from this

\footnotetext{
18 See Anthony D'Amato, International Law as an Autopoietic System, in DEVELOPMENTS Of INTERNATIONAL LAW IN TREATY MAKING 335 (Rudiger Wolfrum \& Volker Röben eds., 2005); see also Oeter, supra note 15, at 84.

19 See NikLAS LUhMANN, SOCIAL SyStems 9 (1995). And, in turn, the operational closure achieved through the recursive linking of system specific communications serves as the "condition of possibility for openness." Id. at 447.

${ }^{20}$ On the role of this functional method which corresponds to systems theory, see id. at 53.
} 
perspective, and wielding the appropriate theoretical tools, reveals an important relationship between international law and the dominant forms of modern society's societal differentiation.

Building upon the foundations of classical sociology, ${ }^{21}$ social systems theory perceives modern society to have emerged through a sequence of several forms societal differentiation. ${ }^{22}$ For present purposes, three forms of differentiation should be noted for their importance. ${ }^{23}$ First, in primitive society, segmentary differentiation dominated where "society [was] structured into various equal, or at least similar, part systems." 24 Second, in Classical Antiquity to the early Middle Ages, stratified differentiation in terms of rank and the creation of a hierarchical social order operated. ${ }^{25}$ Third, in modern society, a functional differentiation occurs with networking of the specialized communications around special "functions to be fulfilled at the level of the society itself." 26 This is an admittedly arbitrary theoretical catalogue, but these various forms of differentiation can be discerned as dominating at different points in the historical development of society, and each form proves highly influential to the evolutionary possibilities of social systems, the formation of norms, and the self-descriptions of social systems. ${ }^{27}$

This theoretical scheme must be developed further by noting the complex integration of these forms of differentiation in modern society. The recent development of world society has made it obvious, for example, that while one form of differentiation may typically gain primacy once it is tried and tested by societal evolution, various forms will always coexist

\footnotetext{
${ }^{21}$ See, Emile Durkheim, The Division of Labour in Society (1964); Shmuel Eisenstadt, Social Change, Differentiation and Evolution, 29 AM. SOC. ReV. (1964); GEORg SIMMEL, THE SOCIOLOGY Of GEORg SIMMEL (Kurt Wolff ed., 1964); MAX WEBER, ECONOMY AND SOCIETY (1968).

22 See Niklas luhmanN, Theory of SOCIety, Vol. 2, 10-13 (2013).

${ }^{23}$ See id. Luhmann also includes differentiation in terms of a center and a periphery which allows for asymmetric relations between different social spheres. This differentiation form is not immediately relevant to the present study, except to note that it allows for the transcendence of the principle of segmentation; see, e.g., IMMANUEL WALLERSTEIN, THE MODERn WORLD-SYSTEM I: CAPITALIST AgRICULTURE AND THE ORIGINS OF THE EUROPEAN WORLD-ECONOMY IN THE SiXTEENTH CENTURY (1974). Drawing upon Foucault, Kjaer also adds another differentiation form, namely "territorial differentiation," to imply a "construction of a limited and coherent geographical space which is clearly demarcated from other geographical spaces within the framework of the modern nation-states," see POUL KJAER, Constitutionalism in the Global Realm: A Sociological Approach 21 (2014). While that may seem relevant to the present study, it only obfuscates matters unnecessarily. What is most relevant for present purposes is the sovereign equality of nation-states, and that is most adequately represented by the segmentary principle of differentiation.

${ }^{24}$ Id. at 13,33 .

$25 / d$.

${ }^{26}$ See Niklas Luhmann, The Differentiation of Society, 2 CAN. J. Soc. 35 (1977).

27 See LUHMANN, supra note 22 , at 11.
} 
and work in symbiosis. ${ }^{28}$ In particular, the organization of world society tends to be heavily dominated by a complex integration of the segmentary differentiation of nation-states and the more primary functional differentiation of society in general. ${ }^{29}$ The symbiosis of these differentiation forms proves especially relevant to international law's structural foundations and the problems it faces today in dealing with jus cogens claims against the state. This can be seen by measuring the international legal system's origin and development in the context of shifting societal differentiation forms.

There is a consensus that modern international law's emergence should be traced to the late Middle Ages..$^{30}$ Grewe, for example, locates the emergence of the modern international legal system within a temporal triangulation of the emergence of Christendom as a community of faith in Europe in the high Middle Ages, its subsequent dissolution in the Reformation in the late Middle Ages, and the demarcation of peace in Europe in $1648 .{ }^{31}$ This is a more pointed analysis than the popular and gross construction of international law's emergence with the Münster and Osnabrück peace treaties which marked the end of the Thirty Years War. ${ }^{32}$ Yet, despite the complexity of the evolution of international law and the mythic status of the Peace of Westphalia, ${ }^{33}$ there is some logic to the view that the emergent sovereignty doctrine that secured the Peace-more than any other historical development-made international law a necessity. ${ }^{34}$

The shift to functional differentiation is seen as occurring at the same time, starting in the "the early seventeenth century," and "made visible by religious wars, by economic

${ }^{28}$ See Mathias Albert, Barry Buzan \& Michael Zurn, Introduction: Differentiation Theory and International Relations, in BRinging SOCIOlogy to INTERnational Relations: World Politics As Differentiation TheOry 3 (Mathias Albert et al. eds., 2013).

${ }^{29}$ This was somewhat neglected by Luhmann. As Munch points out, Luhmann "deals too little" with the complex integration of functional and segmentary differentiation in world society. See Richard Munch, Functional, Segmentary and Stratificatory Differentiation of World Society, in BRINGING SOCIOLOGY TO INTERNATIONAL RELATIONS: WORLD POLITICS AS DifFERENTIATION THEORY 76 (Albert et al. eds., 2013).

30 See, e.g., Wilhelm Wengler, VölKeRReCHt, Vol. 1, 107 (1964); Wolfgang Preiser, History of the Law of Nations: Ancient Times to 1648, in II ENCYCLOPEDIA OF PUbLIC INTERNATIONAL LAW 722 (Rudolf Bernhardt ed., 1995).

${ }^{31}$ See Wilhelm GreWe, The Epochs of International LaW 51-60 (2000).

32 See, e.g., Leo Gross, The Peace of Westphalia 1648-1948, 42 AM. J. OF INT'L LAW 28 (1948); HANS MORGENTHAU, Politics among Nations: The Struggle for Power and Peace 294 (1985); Helmut Steinberger, Sovereignty, in IV ENCYCLOPEDIA OF PUBLIC INTERNATIONAL LAW (Rudolf Bernhardt ed., 1987).

${ }^{33}$ See Andreas Osiander, Sovereignty, International Relations, and the Westphalian Myth, 55 INT'L ORG. 251, 287 (2001); Benno TeschKe, The Myth of 1648: Class, Geopolitics and the Making of Modern International Relations (2003).

${ }^{34}$ See LASSA OPPENHEIM, INTERNATIONAL LAW 44 (1905). 
fluctuations, and geographic and scientific extensions of world views." 35 From this perspective, the crisis of the seventeenth century ${ }^{36}$ resulted from the shift from hierarchical differentiation in the pre-modern era to the functional differentiation of modern society. ${ }^{37}$ The primary differentiation of pre-modern society through stratification allowed for an ordering where the upper stratum could be related to the whole and the dissimilarity in parts could be viewed as natural and as contributing to the whole. Yet, the shift to functional differentiation fragmented the world into a constellation of part-system-specific horizons, in which "all tangible meaning enters the shadow of other possibilities." 38 Each part-system is functionally differentiated, yet all are alike in that none can claim universal validity for its constructed meaning.

Under these fragmented social conditions, the modern political system emerged as a solution to the difficulties of ensuring collective decision-making. ${ }^{39}$ In assuming authority to represent society under such conditions, though, the political system depended upon structural couplings with other functional systems, ${ }^{40}$ as well as the dynamics of functional differentiation itself. ${ }^{41}$ But it also relied upon the symbiosis with another form of differentiation - the segmentary differentiation of nation-states. ${ }^{42}$ The differentiation of the global political system into "units, which are equal and functionally similar to one another" 43

${ }^{35}$ See Luhmann, supra note 26 , at 45.

36 See, e.g., Hugh Trevor-Roper, The Crisis of the Seventeenth Century: Religion, the Reformation \& Social Change (1967) (Hugh Trevor-Roper's account of the crisis of hierarchical authority and the demise of cities).

${ }^{37}$ Luhmann, supra note 26 at 45.

38 See NikLAs LuHMANN, A Sociological TheORY of LAW 148 (2013).

39 See NikLAs Luhmann, The Representation of Society Within Society, in PolitiCal TheORY in the Welfare State 11-20 (1990).

40 Most notably with law, see NIKLAS LUHMANN, LAW AS A SOCIAL SYSTEM 230-273 (2004).

${ }^{41}$ Luhmann's theory of the evolution of the modern state in this respect is complex and there is little space to explore it here. In short, Luhmann claimed that the development relied upon the evolution of the institutions of parliamentary democracy, not as the actualization of consensus, but rather upon the reflexive mechanisms which allowed the state to construct itself as a "formula of unity for the self-description of the political system," and to construct its legitimacy as a "formula for contingency." See NIKLAS LUHMANN, DIE POLITIK DER GESSELSCHAFT 125 (2000); NIKLAS LUHMANn, State and Politics: Towards a Semantics of the Self-description of Political Systems, in POLITICAL THEORY IN THE WELFARE STATE 128 (1990).

42 For accounts of such segmentary differentiation, see, e.g., Niklas Luhmann, Globalization or World Society?, 7 INT'L ReV. OF SOC. 72 (1997); KenNeth WALtZ, Theory of InTERnATIONAL Politics 95 (1979); Mathias Albert \& Barry Buzan, Differentiation: A Sociological Approach to International Relations Theory, 16 EUR. J. INT'L RELATIONS 318 (2010); Munch, supra note 29 , at 71.

43 See Lora Anne Viola, Stratifactory Differentiation as a Constitutive Principle of the International System, in Bringing Sociology to International Relations: World Politics as Differentiation Theory 113 (Mathias Albert et al. eds., 2013). 
supported the functional differentiation of the political system and the larger social system. It established narrow territorial frameworks for communication and opinion-forming about political concerns and a concrete basis for developing the consensus and confidence to bind others by collective decision making. ${ }^{44}$ Moreover, this segmentary differentiation form not only supported the modern political system's functional differentiation, it also provided the framework in which other functional subsystems could develop their autonomy, leading, for example, to a national economy, national science, national health system, national curriculum, national sports, etc. Only over time could these function-systems gradually free themselves from their internal reliance on the "stabilization mechanisms" of such territorial

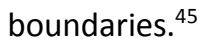

The political system of world society can thus be seen to be divided into political states "not only in the sense of a more or less obsolete survival of history but apparently as a requisite of functional specification." ${ }^{46}$ In order to maintain its function in contributing to meaningful communication in society, law evolved to provide a normative framework for the segmentary differentiation which underpinned this great societal development. Thus, the emergence of international law, and in particular the legal principle underpinning sovereign immunity (par in parem non habet imperium), provided the expectational framework to maintain the segmentary differentiation of the political system, which in turn proved so instrumental in the increasing functional differentiation of modern society.

Examples of such a relationship are evident in the early foundations of international law. For example, sixteenth century Spanish scholars are often credited with first distinguishing international law as jus inter gentes-a concept of an international legal community encompassing the globe. ${ }^{47}$ This concept of the law of nations achieved a move towards more inclusion in the emerging function systems of society. Christian theology was instrumental here, but so was another globalizing functional system-the economy. ${ }^{48}$ As Vitoria argued

\footnotetext{
${ }^{44}$ See LUHMANN, supra note 38, at 259.

45 See Poul Kjaer, The Concept of the Political in the Concept of Transnational Constitutionalism: A Sociological Perspective, in After Globalization: New Patterns of Conflict and Their Sociological and Legal Reconstruction 4 (Christian Jorges \& Tommi Ralli eds., 2011)

${ }^{46}$ See Luhmann, supra note 26 , at 41 (emphasis added).

47 See JAMES BroWn SCOtT, THE SPANISH ORIGIN Of INTERNATIONAL LAW: FRANCISCO de VITORIA AND HIS LAW Of NATIONS (1934); GreWe, supra note 31, at 25; J.A. Fernández-SANTAMARIA, The State, War and PeAce: Spanish Political Thought IN the RENAISSANCE 1516-1559, 61 (1977).

${ }^{48}$ According to Parry's account of the Age of Reconnaissance, the two principle motives which impelled Europeans to venture overseas in the sixteenth century were "acquisitiveness and religious zeal." See JOHN PARRY, THE AGE OF RECONNAISSANCE: DisCOVERY, EXPLORATION AND SETtLEMENT FROM 1450 to 1650, 19 (1963).
} 
that human beings were sociable in nature ${ }^{49}$ Spanish conquistadors were held to be entitled to have commercial dealings with the indigenous people of the Americas. ${ }^{50}$ Of course, inclusion in the global expansion of function systems is not necessarily altruistic - rather it can be insatiable, colonizing, and destructive. As pointed out by Onuma, if the aboriginals hindered their commercial activities, "the Spaniards could resort to war and realize their rights," just as if the aboriginals hindered their mission to propagate Christianity, "they could resort to war, depose the Indian ruler and establish a new ruler." ${ }^{51}$ To support this, sovereignty doctrine emerged to lend a "coercive property to the jus gentium," and serve as the basis of a just war against any aboriginals hostile to Spanish expansion of global commerce and religion. ${ }^{52}$ And it is of utmost relevance to the present discussion that the paradox of this jus gentium was dissolved, and international law progressed, through the use of judicial distinctions-this time between binding (praescriptio) and recommendatory (concessio) provisions of natural law. ${ }^{53}$

The connection between sovereignty doctrine and the functional differentiation of society is even clearer in the seventeenth century. For example, the work of Grotius - the so-called father of international law-can be linked to the global expansion of the economic system and the more general shift to functional differentiation. Grotius, after all, was employed by the Dutch East Indies Company, ${ }^{54}$ and developed his own concept of societas humana in the interests thereof. ${ }^{55}$ Moreover, Grotius is often credited with being the first to substantially develop the sovereign equality principle. ${ }^{56}$ Thirty years before the Peace, Grotius became renowned for his treatise de Mare Liberum which presented the territorial limitation of sovereignty as the positive law of nations, and subsequently this very idea "was given

\footnotetext{
${ }^{49}$ See Francisco de VITORIA, De IndIS RelECtIO PRIOR (John Pawley Bate trans., 1917); see also GreWE, supra note 31, at 145.

50 See also ANTHONy ANGHIE, IMPERIALISM, SOVEREIGNTY, AND the MAKING Of INTERNATIONAL LAW 13-28 (2004); cf. Luhmann, supra note 26 , at 40 ("If every individual is acknowledged as choosing or not choosing a religious commitment; and if everybody can buy everything and pursue every occupation, given the necessary resources, then the whole system shifts in the direction of functional differentiation.").

${ }^{51}$ See Yasauki Onuma, When was the Law of International Society Born? An Inquiry into the History of International Law from an Intercivilizational Perspective, 2 J. THE HIST. INT'L L. 25 (2000); see also, FERNÁNDEZ-SANTAMARIA, supra note 47 , at $84-85$.

52 See FERNÁNDEZ-SANTAMARIA, supra note 47, at 62; ANGHIE, supra note 50, at 16, 24.

53 See Martti Koskenniemi, Empire and International Law: The Real Spanish Contribution, 61 U. OF TORONTO L. J. 14 (2011).

54 See Peter Borschberg, hugo grotius, the Portuguese, and Free Trade in the East Indies (2011).

55 See GREWE, supra note 31, at 149.

${ }^{56}$ See id. at 119; AthenA Efraim, SOVEREIGN (In)EQUALITY IN INTERNATIONAL ORgANIZATIONS 64 (1999).
} 
concrete expression in the Peace of Westphalia." ${ }^{57}$ In doing so, Grotius not only rejected English and Spanish claims over the oceans and thereby promoted the particular interests of a Dutch Republic which had relatively few natural resources or territory of its own, ${ }^{58}$ but advanced the global expansion of the economy.

The development of international law and sovereignty doctrine can thus be said to correspond to the functional differentiation of society. Of course, the relationship has been complicated in recent years by international law's increasing concurrent reference to a global public sphere, which will be discussed below, but there is nothing to suggest that globalization eroded state sovereignty. Despite increased communication at the global level, the developed autonomy of function systems like the economy and science at the global level, and even concerted efforts to establish political decision-making at the supra-national level, the need for more limited territorial frameworks for consensus in political decision making remains obvious. It is clear that sovereignty persists in world society as a "complex aggregate of practices," many ways to meaningful communication and the reproduction of world society. From this perspective, international law's functional reference to state sovereignty may be explained by the importance of this segmentary form of differentiation to functionally differentiated society. In other words, the character of international law and its transformations do not simply depend on "the structure of the modern nation state system," ${ }^{160}$ but also on the continued symbiosis of this form of differentiation and the functional differentiation of modern society.

In the past century there has, nonetheless, been a concurrent globalization. With the increasing constitution of world society as a communicative network beyond the state, a global public sphere emerged, formulating and channeling expectations of peremptory norms. This, too, is a result of the primary functional differentiation of society, albeit at a more advanced stage than has been addressed so far. Social systems may establish recursive communication around a solution to a basic societal problem, yet with the solipsistic development and deviation of part-systemic communication, society has been confronted with the dark side of functional differentiation. ${ }^{61}$ When the inherent disequilibria of this form of differentiation is placed in the context of its symbiosis with the segmentary

\footnotetext{
57 See Hedley Bull, The Importance of Grotius in International Relations, in HUGo GrotIUS AND INTERNATIONAL RELATIONS 75 (Hedley Bull et al. eds., 1992).

58 See Steinberger, supra note 32, at 504; GREWE, supra note 31, at 265.

59 See Chris Thornhill, National Sovereignty and the Constitution of Transnational Law: A Sociological Approach to a Classical Antinomy, 3 Transnat'L Legal THEORY 408 (2012).

${ }^{60}$ See GREWE, supra note 31, at 13.

61 See Gunter Teubner, A Constitutional Moment? The Logics of 'Hit the Bottom', in THE FINANCIAL CRISIS IN Constitutional Perspective: The Dark Side of Functional Differentiation 14 (Poul Kjaer et al. eds., 2011).
} 
differentiation of independent sovereign states, such developments appear all the more threatening to an emergent global society, and ultimately generate the increased formulation of norms at the global level. How else should world society react if, for example, science has made it possible to produce energy from nuclear fission for national military purposes? As technology develops, these dangers appear as risks taken by decision-makers and they will be subject to opposition and normative demands at the global level for change. ${ }^{62}$ To use the example above, no one will make normative demands in relation to the nuclear fission involved in the birth of a star, but they can, and do, when the process is developed by decision makers for national interests.

International law cannot ignore the increasing expectations of global public order that result from advanced functional differentiation. It is not simply that international law suffers some "Messianic structure" 63 that compels it to represent expectations of peremptory norms, nor is such a universalism purely a result of ideological bases that dominate the self-description of international law. ${ }^{64}$ Advanced functional differentiation, both through reaction to the unchecked autonomy of differentiated function systems and the development of world society as a communicative network, has led to the increasing formulation of highly generalized expectations at the global level. Despite their general nature, these expectations are more concrete than values, and although they may lie largely "beyond the established juridical world of forms" ${ }^{\prime 65}$ they are not simply a functional reference for morality. Instead they increasingly emerge as a "normative institutionalization of value commitments," and "normative expectation of normative expectations." ${ }^{66}$ They are formulated, in other words, as claims to peremptory norms, and they find cogent expression in positive law, in claims submitted before courts, in amicus briefs, in the decisions and communications of formal civil society organizations, and in the adjudications and judicial devices employed by courts deciding such claims.

Law's autonomy may depend upon its own selection of norms for legal institutionalization, nevertheless, when expectations of collective goods are so cogently formulated at the global level that they impinge upon meaningful communication, law will at least strive to stabilize such expectations or will surrender its functional relevance to society in this respect. ${ }^{67}$ Although the limits of law have been tested by increased expectations of jus cogens, law has by no means surrendered its functional relevance to such expectations-not yet at least.

\footnotetext{
${ }^{62}$ See NiKLAS LUHMANN, RISK: A SOCIOLOGICAL THeORy (1993).

${ }^{63}$ See Martti Koskenniemi, What is International Law For?, in InTERnATIONAL LaW 49 (Malcolm Evans ed., 2014).

${ }^{64}$ See Sundhya Pahuja, Decolonising International 40 (2011).

${ }^{65}$ See LUHMANN, supra note 40, at 469 (emphasis added).

${ }^{66}$ See id. at 468.

${ }^{67}$ See LUHMANN, supra note 38.
} 
In general, then, the dilemma for international law in dealing with conflicting claims of jus cogens and state immunity is a definite product of functional differentiation. On the one hand, the legal system remains functionally orientated towards the segmentary differentiation of the global political system which supports the primary differentiation of modern society. On the other hand, it strives to maintain functional reference towards the expectations of peremptory norms and underlying global public order which are generated by the side-effects of advanced functional differentiation. The paradox of this duality has been well noted in different forms. ${ }^{68}$ What has received less attention, though, are the mechanisms international law employs to maintain a simultaneous functional reference to the conflicting expectations, how it sustains itself under these conditions, and what a formidable solution it has innovated in this respect.

\section{Judicial Solutions to the Problem of Jus Cogens and Sovereign Immunity}

As social systems differentiate themselves through the recursive self-reference of the communications which accrue around certain problem-solution relationships, one of the most successful mechanisms for securing this autopoiesis is the internally constructed binary code. ${ }^{69}$ These are codes containing a distinction between a positive and negative value, but which are premised on the specific functional reference of social systems and "translate the viewpoint of the function into a guiding distinction" to structure the system's communication. ${ }^{70}$ Thus, the science system primarily structures its communication in terms of a distinction of true/false, the economy in terms of ownership/non-ownership, the mass media in terms of information/non-information, the legal system in terms of legal/illegal, etc. The code's form is contingent-it may, for example, be legal/illegal or it may be a functionally equivalent distinction. What is important is that the code serves the "recursive reproduction of special (social) function systems." ${ }^{\prime 71}$

Binary codes are useful in this sense as they offer a totalizing construction, whereby everything in the world can be addressed by the system according to one or the other value and thus allow the system to claim universal validity in terms of a specific functional reference. $^{72}$ Moreover, the distinction in the code secures the connectivity of operations in the system and generates further communication. All communications that fall within the positive value of the code are actualized as information in the system and painted as

\footnotetext{
68 See Martti KoskenNiemi, From Apology to Utopia (1989) (the most well-known example).

${ }^{69}$ See NikLas LuHManN, Ecological Communication 38 (1989).

70 See NikLAs LUHMANN, ART AS A SOCIAL SyStEM 186 (2000).

71 See NiKLAs LUHMANN, A Systems TheORy of RELIgION 88 (2013).

${ }^{72}$ Id. Though such a claim to universal validity is always precocious, as it is always open to functional equivalence.
} 
successful, and thereby stand a better chance of being condensed, generalized, and repeated in other contexts. But, the operative proximity of the binary values means the counter-value value is always present as a reflexive control value to highlight other possibilities and add a degree of contingency to stimulate communication. In short, by providing a positive value to actualize information in the system and yet permitting no "finality" or "perfection,"73 binary codes achieve the recursivity of internally structured communication, and thus the functional system's operational closure.

This abstract theory of the role of binary codes in securing social systems' autopoiesis can be presented on a more empirical level through the example of how the courts have responded to the problem of balancing global public order and state sovereignty. Traditionally, the serving distinction in this respect was between individual and state responsibility. International criminal law, for example, has been able to expand without undermining its Westphalian foundations by sidestepping the sovereign immunity problem through a distinction between the "men" who commit international crimes and states as "abstract entities" which do not. ${ }^{74}$ For example, when the United Kingdom House of Lords denied the former Chilean head of state immunity ratione materiae for acts which they considered a jus cogens violation, ${ }^{75}$ they relied heavily upon the distinction between the "responsibility of the state" and the "individual responsibility."76 They were emphatic that Senator Pincohet was not coming under their jurisdiction as the head of a state which had committed torture, but because he allegedly "incurred direct criminal responsibility for his own acts in ordering and directing a terror campaign involving the use of torture."77 In short, by employing this device, it is the individual who is denied immunity from prosecution and not the state, and thus sovereign equality is "not an issue."78

\footnotetext{
${ }^{73}$ See LUHMANN, supra note 40, at 193.

${ }^{74}$ See Trial of the Major War Criminals Before the International Military Tribunal, Vol. I 223 (Nüremberg, 1947) (https://www.loc.gov/rr/frd/Military_Law/pdf/NT_Vol-I.pdf).

${ }^{75}$ See R. v. Bow Street Metropolitan Stipendiary Magistrate, ex parte Pinochet Ugarte (No. 3) (1999) 2 All E.R. 97. It is often overlooked that the House of Lord's decision to deny the former head of state immunity ratione materiae was based not on a violation of jus cogens, but rather on the authority of the 1984 Torture Convention which was incorporated into English law by the Criminal Justice Act 1988; see id. at 114 (as per Lord Browne-Wilkinson, "the Torture Convention did provide what was missing."); see also Dinah Shelton, Normative Hierarchy in International Law, 100 Am. J. Int'l L. 316 (2006).

${ }^{76}$ See R. v. Bow Street Metropolitan Stipendiary Magistrate at 166 (Lord Hutton).

${ }^{77}$ See R. v. Bow Street Metropolitan Stipendiary Magistrate at 178 (Lord Millett).

78 See Thomas Weatherall, Jus Cogens and Sovereign Immunity: Reconciling Divergence in Contemporary Jurisprudence, 46 GEO. J. OF INT'L L. 1175 (2015).
} 
This distinction has not proved supple enough for the "changing social and political values of the international community." ${ }^{\prime 79}$ In particular, international courts without jurisdiction to prosecute crimes or provide civil remedies ${ }^{80}$ are increasingly confronted with direct claims of state responsibility for violations of jus cogens. In effect, these claims have thrown down the gauntlet for international law, presenting the most cogent formulation of the dual functional reference problem: Is such a legal system simply there for maintaining comity between nation-states or is it part of a global legal order? The distinction between substance and procedure which the courts developed to solve this problem announces a "third model" in the history of state immunity's legal development. ${ }^{81}$ From a systems theoretical perspective, it is one of the most important developments of international law in recent years.

\section{The Substance/Procedure Code and the Continued Functional Relevance of Law in World Society}

Although the use of this distinction was mostly developed by the International Court of Justice (World Court ${ }^{82}$ ), it was the European Court of Human Rights which first formulated this distinction in the context of the state's jurisdictional immunity. In the Al-Adsani case, the Strasbourg Court found that the UK did not breach the applicant's Article 6 right because it could not establish as a matter of international law that "a State no longer enjoys immunity from civil suit." ${ }^{13}$ Nonetheless, the Court stated aside that "[t]he grant of immunity is to be

79 See Hazel Fox \& Philippa WebB, The LaW of State IMmunity 26 (2015).

80 See Bouzari v. Islamic Republic of Iran, [2002] 124 ILR 427, aff'd, [2004] 243 DLR (4th) 406, para. 91 (Can. Ont. Sup. Ct.). Municipal courts have generally rejected civil claims for jus cogens violations on the basis that they come too close to "subjecting one state to the jurisdiction of another." Nevertheless, under the normative rupture of globalized society, neither practice nor logic appear to support the distinction of criminal proceedings as relating only to prosecution of the individual and civil proceedings as encroaching upon the sovereign immunity of the state. Special Rapporteur Roman A. Kolodkin, Second Report on Immunity of State Officials from Foreign Criminal Jurisdiction, International Law Commission, ๆ 66 U.N. Doc. A/CN.4/631 (2010). Recently, a U.S. District Court denied the former Prime Minister of Somalia immunity in a civil suit for violations of jus cogens in Yousuf v. Samantar, 699 F.3d 763, 776 (4th Circ. 2012), ultimately leaving the law in this area in a "state of flux." Jones and Others v. The United Kingdom, Eur. Ct. H.R., para. 213 (2014).

81 See Fox \& WEBB, supra note 79, at 38.

82 See The reference to the World Court is commonly used with little reflection. It appears, though, that the practice is based on a predominant statist concept of world society at the time of the Court's foundation. For example, according to Rosenne, the moniker is warranted by the recognition of the Court as the principal judicial organ of the United Nations, the fact that all members of the United Nations are ipso facto parties to the Statute of the Court, and the fact that non-members states can also be parties before the Court. SHABATAI ROSENNE, THE WORLD COURT AND HOW IT WORKS 23 (Terry Gill ed., 2003). Nevertheless, the label is used differently here to highlight that, despite the statist foundations of the term, the Court must, in the absence of alternative legal structures, strive at an operational level to be a principal institution for expectations not only of sovereign states, but of a much broader world society.

${ }^{83}$ See Al-Adsani v. United Kingdom, App. No. 35763/97, para. 61 (2002). 
seen not as qualifying a substantive right but as a procedural bar on the national court's power to determine the right." ${ }^{84}$ From then on, the distinction of substantive/procedural law seems to have crystallized in judicial semantics in this area. In 2006, the World Court was confronted with the question as to the relationship between jus cogens and state sovereignty when the Democratic Republic of the Congo argued that Rwanda's reservation to the Court's jurisdiction was null and void in relation to jus cogens violations. ${ }^{85}$ The Court rejected the argument, stating that the fact that a dispute relates to compliance with a peremptory norm "cannot of itself provide a basis for the jurisdiction of the Court to entertain that dispute." 86 Jus cogens and the establishment of jurisdiction were "two different things," the Court said. ${ }^{87}$ The same year, the House of Lords applied this approach in the case of Jones v. Saudi Arabia, ${ }^{88}$ with both Lord Bingham and Lord Hoffmann ${ }^{89}$ further citing Hazel Fox's argument that state immunity is a procedural rule that does not "go to substantive law" and "does not contradict a prohibition contained in a jus cogens norm but merely diverts any breach of it to a different method of settlement." 90

By 2012, the judicial formula had slotted into place. In the Jurisdictional Immunities case, the World Court adjudicated a dispute in which Italy claimed that Germany was subject to the civil jurisdiction of Italian courts for acts committed on Italian territory by the Werhmacht during the Second World War, and in which Germany claimed its right to immunity under customary international law. ${ }^{91}$ In its judgment, the Court emphasized that it was "addressing only the immunity of the State itself," and not the immunity that would apply in criminal proceedings against a state official. ${ }^{92}$ The Court then immediately turned to considering Italy's claim of an exception to state immunity on the basis of the jus cogens status of the norms violated. Such an argument, the Court held, depends upon the "existence of a conflict between a rule, or rules of jus cogens, and the rule of customary law which requires one

\footnotetext{
${ }^{84} / d$. at para. 48.

${ }^{85}$ Rwanda contested the Court's jurisdiction based on its reservation to Article IX of the 1948 Genocide Convention. See Armed Activities on the Territory of the Congo (Dem. Rep. Congo v. Rwanda), Jurisdiction and Admissibility, Judgment, I.C.J. Rep. 2006 (hereinafter Armed Activities).

${ }^{86} / d$. at para. 64.

${ }^{87} / d$.

${ }^{88}$ See Jones v. Saudi Arabia [2006] UKHL 26, para. 24.

${ }^{89} / d$. at paras. $24,44$.

90 See Hazel Fox, The Law of State Immunity 525 (2002).

${ }^{91}$ See Jurisdictional Immunities, supra note 5.

${ }^{92} / d$. at para. 91.
} 
State to accord immunity to another." ${ }^{93}$ Yet the Court believed that "no such conflict exists." ${ }^{\prime 94}$ Accordingly, the Court declared that:

The two sets of rules address different matters. The rules of State immunity are procedural in character and are confined to determining whether or not the courts of one State may exercise jurisdiction in respect of another State. They do not bear upon the question of whether or not the conduct in respect of which the proceedings are brought was lawful or unlawful. ${ }^{95}$

To support this approach, the Court cited its previous decisions in both the Armed Activities case and the Arrest Warrant case, ${ }^{96}$ and further cited municipal cases upholding state immunity in respect of civil claims for jus cogens violations. ${ }^{97}$ None of this should mask the boldness of the Court's approach, though-the only place the Court explicitly refers to the distinction of substantive/procedural law in the Arrest Warrant case is to support the international criminal law exception to immunity ratione personae, ${ }^{98}$ while the cited municipal cases clearly relied upon the internally constructed criminal/civil law distinction to uphold immunity.

Such a bold step was necessary to secure law's expansion in a globalized society. Under such conditions, courts cannot determine the legality or illegality of jus cogens or state immunity in relation to each other, yet the substantive/procedural law distinction provides courts with something that is altogether more "utterable." ${ }^{\text {"99 }}$ With it, the unity of the jus cogens paradox in a world of sovereign states could be "replaced by a difference." ${ }^{100}$ As Weatherall puts it, under the substantive/procedural distinction employed by the Court, jus cogens and state

\footnotetext{
${ }_{93} / d$. at para. 93.

${ }^{94} \mathrm{See}$ Jurisdictional Immunities, supra note 5.

${ }^{95} \mathrm{Id}$.

${ }^{96} / d$. at para. 95.

$97 / d$. at para. 96.

98 "While jurisdictional immunity is procedural in nature, criminal responsibility is a question of substantive law. Jurisdictional immunity may well bar prosecution for a certain period or for certain offences; it cannot exonerate the person to whom it applies from all criminal responsibility." See Arrest Warrant of April 11, 2000 (Dem. Rep. Congo v. Belgium), Judgment, I.C.J. Rep. para 602002.

${ }^{99}$ See ANdREAS Philippopoulos-MiHAlopoulos, NiKLAS LUHMANN: LAW, JustiCE, SOCIETY 74 (2010).

${ }^{100}$ See LUHMANN, supra note 69 , at 37.
} 
immunity are treated like "ships passing in the night." 101 In this way, law can treat the two incompatible norms as "two different things," "two sets of rules addressing different matters." ${ }^{102}$ As long as they can be constructed as not interplaying with each other in this way, the paradox is thereby dissolved as far as legal operations are concerned. Moreover, the form of the binary code also "unfolds" the paradox which lingers in the distinction which the legal system has employed to overcome the problem. ${ }^{103}$ As the two sides of a distinction cannot be used at the same time in the moment of legal communication, the binary code removes the problem that its own unity is constituted by two incompatible values. Thus, as the code's proponents assert, the distinction does not contradict jus cogens, but merely diverts its actualization to another legal forum. ${ }^{104}$ It does not, in other words, become a stalling contradiction for legal communication.

The operative proximity of the substantive and procedural values in the code also plays an important role in securing the autopoiesis of the legal system. In using a binary code, "there cannot be a decision on one value without having regard to the other." 105 Thus, even though courts have consistently opted for the procedural side of the distinction in upholding state immunity while diverting the substance of jus cogens to another forum, and even if this comes to be seen as the correct judicial response in such disputes, the repeated use of the binary code to overcome the jus cogens paradox in a world of sovereign states will open up international law. Although courts may employ the distinction and opt for immunity as procedural, the other side of the distinction will always operate as a control value which presents the possibility of future judgments actualizing the substantive value of jus cogens. While this may not satisfy those viewing the substance/procedure distinction as artificial and inconsistent, and who call for the immediate operative primacy of jus cogens over state immunity, ${ }^{106}$ this temporalization of the substantive value of jus cogens should not be overlooked. At the very least, it must be recognized that the distinction allows courts to generate conflicts and legal communication, and ultimately find a way out of the cul-de-sac they find themselves in without surrendering a reference to either state sovereignty or peremptory norms.

The pivotal achievement of the substantive/procedural binary code is uncertainty. Luhmann specifically pointed to the general distinction between substantive and procedural law as

\footnotetext{
${ }^{101}$ See Weatherall, supra note 78 , at 1152.

102 See Jones v. Saudi Arabia, supra note 88; Talmon, supra note 6, at 980.

103 Luhmann sees paradoxes as creative, because "one has to try so hard to avoid and to conceal it." See LUHMANN, supra note 40, at 177. 
one of law's "most important evolutionary achievements." 107 Not only does the substantive/procedural law distinction leave the more basic binary code of legal/illegal intact and avoid introducing further values or super-values, but it also presents a not yet finding, making it clear that "the proceedings are not yet over and that the result is still uncertain." 108 This is exactly what is achieved by the courts' binary coding of jus cogens as substantive and state immunity as procedural. The distinction leaves the code of legal/illegal intact for further adjudication of these norms, and it allows courts to avoid relying on any super values imposed by the general social environment. Most importantly, by attributing state immunity to the procedural value and jus cogens to the substantive value, the law presents a not yet finding in which it holds itself out as possibly-under different circumstances in the future-upholding the peremptory status of those norms. Again, the law uses uncertainty in this way to avoid a cul-de-sac and to offer further opportunities and to encourage further participation. ${ }^{109}$ Some may see it as a denial of justice and some may see it as merely diverting the actualization of jus cogens to another forum. Yet, the code itself provides no definitive answer or finality in this respect.

It is important to note, though, that this is not simply about the autopoiesis of law and the way in which the legal system stops itself from running aground in the face of the jus cogens paradox in a world of sovereign states. As much as international law achieves operational closure using such codes, it does so because it is open to behavioral expectations in global society. ${ }^{110}$ And the way in which international law relies upon a binary code of substantive/procedural law to address the conflict of jus cogens and state immunity must be recognized as maintaining a functional reference to both of those normative expectational structures. Again, this may be less obvious with respect to the jus cogens, but in attributing state immunity to the procedural value, the courts still bear witness to and coexpect peremptory norms as an institutionalized third party-and this judicial recognition "still has the merit of being universal" in this respect. ${ }^{111}$ Furthermore, in excluding claims on procedural grounds, courts do not deny, and at points explicitly recognize, that norms like the prohibition of torture or genocide belong to the jus cogens category. ${ }^{112}$ Finally, the way

\footnotetext{
107 See LUHMANN, supra note 40, at 207.

$108 / d$.

109 Id. at 206.

110 On the relationship between function and code in relation to law, see Luhmann, id. at 294, and on this relationship in general, see LUHMANN, supra note 22 , at 90.

111 See Anne Peters, Let Not Triepel Triumph-How to Make the Best Out of Sentenza No. 238 of the Italian Constitutional Court for a Global Legal Order, EJIL: TALK! (2014), https://www.ejiltalk.org/let-not-triepel-triumphhow-to-make-the-best-out-of-sentenza-no-238-of-the-italian-constitutional-court-for-a-global-legal-order-part-i/.

112 See, e.g., Armed Activities, supra note 85, at para. 64. Nonetheless, the Court's wording in the Jurisdictional Immunities case could be a careless reversal of this trend in that it was only prepared to assume for the sake of rhetoric that "the rules of the law of armed conflict which prohibit the murder of civilians in occupied territory, the
} 
in which courts produce uncertainty through the use of the distinction provides at least some stabilization of expectations that law will at some point in the future uphold the peremptory status of the norms that are fundamental to global public order. In other words, international law's use of the distinction allows for the congruent generalization of expectations of jus cogens in the social, factual, and temporal dimensions. ${ }^{113}$ Measuring up to such a meticulous analysis of the function of law, it can be asserted with confidence that the distinction is functionally related to jus cogens and the global public order.

There is no doubt, though, that in relying on this distinction the courts are skating on thin ice. Ultimately, the distinction is limited in that courts can only rely on procedure without exploring the substantive side of the distinction for so long before the practice becomes more conspicuous as a denial of justice. ${ }^{114}$ Moreover, the binary code adopted by the courts for the problem is not unassailable; it can still be re-paradoxified with relative ease by pointing out, for example, that "one distinctly procedural aspect of jus cogens is its relationship to universal jurisdiction, while a court's subject-matter jurisdiction cannot be completely divorced from substantive considerations." ${ }^{115}$ Nonetheless, the distinction that the courts have developed has, for now at least, proved stable enough to generally suspend the question. Indeed, it has generated debate about which norm (jus cogens or state sovereignty) should take precedence. The courts, therefore, ought to be credited for unfolding the paradox of jus cogens in a world of sovereign states and allowing international law to develop in functional reference to both polar positions. The distinction is another delicate legal operation to temper the flawed specialization of society in which global public order can only be secured within a political institutional framework premised on the segmentary differentiation of nation-states.

\footnotetext{
deportation of civilian inhabitants to slave labor and the deportation of prisoners of war to slave labor are rules of jus cogens." See Jurisdictional Immunities, supra note 5, at para. 93.

${ }^{113}$ On this account of the function of law, see LUHMANN, supra note 38.

${ }^{114}$ See LUHMANN, supra note 40, at 286.

${ }^{115}$ See Weatherall, supra note 78 , at 1152.
} 


\section{Conclusion}

The jus cogens doctrine has been described as an "empty box,"116 a vehicle that "does not leave the garage very often,"117 and "an insubstantial image of a norm, lacking flesh and blood." ${ }^{118}$ But the foregoing analysis suggests that the ability to deploy and make use of the strange jus cogens doctrine now sets the standard for the practice of international law. ${ }^{119}$ There is no stalling contradiction between the emptiness and centrality of jus cogens at the axis of the international legal system. International law has been built upon the sovereign equality of nation-states, and yet society's globalization over the past sixty years has resulted in increased expectations of global public goods as the "the most sovereign all goods." 120 With this, public international law must strive to maintain a simultaneous reference to state sovereignty and the normative hierarchy of a global public order. Among other things, this requires the deft touch of those who can keep the box of jus cogens intact-a promise to be fulfilled-without yet fulfilling it in any concrete sense.

There should, nonetheless, be more reflection on what international law has achieved through its binary coding in response to the conflict between jus cogens and state immunity. This is an area that remains "under-studied and under-theorized." ${ }^{121}$ Admittedly, some recognize the promise of justice to come in the distinction, ${ }^{122}$ but this should be based on a proper contemplation of the operation and function at play in the distinction. Only on this basis is there any opportunity for developing international law's functional reference to peremptory norms and an emerging global public order. While it is true that the substance of jus cogens has so far only operated as a control value to highlight the contingency of state sovereignty, it must be recognized that this is still a singular expression of law's functional reference to jus cogens, and thus the basis of any potential substantive development of jus cogens in international law.

\footnotetext{
${ }^{116}$ See Georges Abi-Saab, The Third World and the Future of the International Legal Order, 29 REVUE EGYPTIENNE DE DROIT INTERNATIONAL 53 (1973).

117 See lan Brownlie, Discussion, in CHANGE AND STABILITY IN INTERNATIONAL LAW-MAKING 108, 110 (Antonio Cassese \& Joseph H. Weiler eds., 1988).

${ }^{118}$ See Anthony D'Amato, It's a Bird, It's a Plane, It's Jus Cogens, 6 ConN. J. INT'L L. 1 (1990).

${ }^{119}$ See comments of Professor Jean D'Aspremont, Jus Cogens: A Social Construct Without Pedigree, Mississippi College School of Law, May 8, 2015 ("You are not really an international lawyer if you do not understand, and cannot deploy and make use of the doctrine of jus cogens."), https://youtu.be/Np61Xq-JRRM.

120 See What Aristotle deemed the truly political, THE PoLITICS 1252a5-6 (Trevor Saunders ed., 1981).

${ }^{121}$ See André Nollkaemper, International Adjudication of Global Public Goods: The Intersection of Substance and Procedure, 23 EUR. J. INT'L L. 771 (2012).

122 See, e.g., Anne Peters, Immune against Constitutionalization?, IMMUNitIES IN THE AGE Of GLOBAL ConstitutionalisM 18 (Anne Peters et al. eds., 2014).
} 
Of course, the development of international law in this direction will be limited if courts themselves do not recognize and reflect on what they have achieved through their binary coding in response to the conflict between jus cogens and state immunity. Unfortunately, there is some dissonance between the operation and self-description of law in this respect. International lawyers have been blind in this sense to their own coding and have missed opportunities for programming the international legal system to respond more directly and with more ecological awareness to global society's complexity. It seems that the dominating semantic value of law's authority in the national and international political framework continues to undermine this recognition and stops law from owning up to the ways in which it strives to maintain a functional reference to a global public order as well as the sovereignty of nation-states. But courts need to realize that there is nothing naturalistic about jus cogens-it results from the increasing formulation of highly generalized norms in global civil society. The fragmentation which international lawyers have occupied themselves within the past is not simply an institutional fragmentation of the traditional international political and legal system, rather it is a fragmentation of normative institutionalization and public authority out beyond the nation state.

For both the academy and the courts at the center of the international legal system, this recognition will depend on finally integrating a sociological perspective that focuses on how "[l]aw constitutes society in so far as it is, itself, an aspect of society, a framework and an expression of understandings that enable society to exist." 123 This is necessary because international law does not have the luxury of limiting its functional reference through the framework of self-contained regimes of the state or federation of states. If international lawyers wish to develop international law to respond to emerging expectations of global public order, then they will need to graduate beyond the superannuated methods which focus upon good legal argument and which reject "convincing sociological descriptions." 124 Instead, they should develop theoretical reflection and empirical identification of the structural bases of public authority and international law's function in the complexity of globalized society.

There is nothing essential about this development of international law, though. This Article has argued that, even without critical reflexivity, international law has managed through its operations to maintain a dual-functional reference to conflicting structures of globalized society. Moreover, even if international law is soon outpaced in this respect by globalization, and the international legal system runs aground in reference to expectations of global public order, there is no doubt that it will be substituted in this respect by a functional equivalent.

\footnotetext{
${ }^{123}$ See Roger Cotterrell, Why Must Legal Ideas be Interpreted Sociologically?, 25 J.L. \& Soc. 2, 182 (1998).

${ }^{124}$ See Martti Koskenniemi, The Methodology of International Law, Max PLANCK ENCYCLOPEDIA OF PUBLIC INTERNATIONAL LAW (2007).
} 